\title{
LEMORZSOLÓDÁSI KOCKÁZATOK A FELSŐOKTATÁSBA KERÜLÉS ELŐTT
}

\author{
JÓZSA GABRIELLA \\ Debreceni Egyetem, Humán Tudományok Doktori Iskola
}

\begin{abstract}
A felsőoktatás átalakulásával a hallgatói társadalom is átalakult. A hallgatói összetétel heterogenitásával megjelent a lemorzsolódás jelensége, ami nemcsak a felsőoktatást és Magyarországot érinti, hanem a közoktatást és szinte az egész világot. Számos szerző hangsúlyozza az első egyetemi év jelentőségét (Horn 1998), hiszen ekkor szocializálódik az egyén az egyetem világába (Pusztai 2011). Munkámban arra keresem a választ, hogy a továbbtanulás előtt álló szakgimnáziumokba járó diákok körében milyen korai lemorzsolódáshoz vezető kockázati faktorok azonosíthatók, és ezek mennyiben különböznek a gimnáziumból jelentkezőkétől. A 2017-es felvételi adatbázis alföldi régióiban található középiskolákból jelentkező tanulókat vizsgáltam. Az eredmények azt mutatják, hogy nem minden rizikófaktor tekintetében lehet egyértelmüen beazonosítani az intézményi különbséget.
\end{abstract}

Kulcsszavakः felsőoktatás, szakgimnázium, lemorzsolódás

With the changes of higher education the student society has also adopted. From the heterogeneity of students appeared the phenomenon of dropout. This not only relates to higher education and Hungary, but also to public education and nearly the whole world. A number of authors highlight the importance of the first year (Horn 1998), because this is the time when the individual adapts to the university atmosphere (Pusztai 2011). In my thesis I investigate what risk factors leading to early drop-out can be identified among students of going vocational school prior to higher education, and how these vary among grammar school students. I examined students from secondary education in the Great Plain Regions based on application database of 2017. The results show, that not all risk factors allow for the clear identification of institutional differences.

Keywords: higher education, vocational school, dropout

Levelező szerző: Józsa Gabriella, DE BTK Neveléstudományi Doktori Program, 4032 Debrecen, Egyetem tér 1. E-mail: jszgabi@gmail.com 


\section{Bevezetés}

A lemorzsolódás jelensége szinte minden országot érint, csupán a mértéke különböző. Jelen van mind a közoktatásban, mind a felsőoktatásban. A közoktatásban a tankötelezettség felső korhatáráig - ami törvény ${ }^{1}$ szerint 2012 . szeptember 1-jétől a 16. életévet jelenti - tartják számon a tanulók iskolai életútját, ám az életkor betöltése után már nincs utánkövetési kötelezettsége az intézményeknek, vagyis nem követik nyomon, hogy mi történik a gyermekkel. Hasonló tendenciát figyelhetünk meg a felsőoktatásban is, bár az utóbbi évtizedekben igen határozott törekvés jelent meg a felsőoktatáspolitikai elvárásokból kiindulva annak érdekében, hogy csökkentsék a hallgatói lemorzsolódást, illetve feltárják ezek okait. Munkámban a gimnáziumokban és a szakgimnáziumokban végzett tanulók felsőoktatási jelentkezéskor azonosítható lemorzsolódási rizikófaktorait és a két intézménytípus közötti különbségeket kívánom feltárni.

\section{Demokratizálódás, expanzió, tömegesedés a felsőoktatásban}

A felsőoktatás intézményrendszere sok változáson ment keresztül az évszázadok során (Hrubos 1999), mely átalakulás a hallgatói populációt is érintette (Pusztai 2011). Az oktatás demokratizálódásával szélesedett az a társadalmi réteg, amelyik számára elérhetővé vált az egyetemi oktatás (Berde 2013; Polónyi 2017; Veroszta 2010). A megnövekedett társadalmi igények hatására tágult a felsőoktatás hálózata, bővült az intézményi kínálat, melynek társadalmi oldala a tömegesedés, létszámnövekedés (Kozma 2004). A felsőoktatásban megjelenő új társadalmi csoportok következtében „egyre mélyebbről kényszerül meríteni az érettségizettek kínálatából" (Sáska 2014: 16). Bekerültek az etnikai kisebbséghez, a különböző vallási közösségekhez tartozók, a munkásosztályt képviselők, az idősebb korosztályhoz tartozók és a nők (Engler 2017). Számos hazai és nemzetközi tanulmány foglalkozik ezekkel a hallgatói csoportokkal, akiket nem tradicionális/nem hagyományos jelzővel illetnek (Macqueen 2017; Pusztai 2011).

\section{A lemorzsolódás jelensége}

Tinto 1975-ben publikált tanulmánya szerint annak ellenére keveset tudunk a felsőoktatásban zajló lemorzsolódás természetéről, hogy széles szakirodalommal rendelkezik. Több mint negyven év után Fenyves és kollégáinak munkájában azt olvassuk, hogy ez a téma nem kap elég kutatói figyelmet, vagyis ma is érvényes Tinto fenti állítása (Fenyves et al. 2017). Bár számos vizsgálat folyt és folyik a felsőoktatást elhagyók, azok hátterének, okainak vizsgálatára, még több kutatásra van szükség ahhoz, hogy a felsőoktatási lemorzsolódás mibenlétéhez közelebb kerüljünk.

A lemorzsolódásnak többféle definíciója létezik, hiszen az egyes oktatási rendszerek sajátosságai különbözőfélék lehetnek. A nemzetközi lemorzsolódással foglalkozó mérések és módszertanok meghatározásai azt javasolják, hogy korcsoportonként kell definiálni a lemorzsolódás fogalmát (Fehérvári 2008). A felsőoktatásban számos megközelítése

1 2011. évi CXC. törvény a nemzeti köznevelésről (45.\$3. bekezdés). 
létezik a lemorzsolódásnak. Kutatásunkban a felsőoktatási intézményt, oktatást végzettség nélkül elhagyó hallgatókat tekintjük lemorzsolódóknak (Molnár 2012).

A lemorzsolódás jelensége, az alacsony diplomaszerzési arányok negatív képet mutatnak az egyén, az intézmény és az össztársadalom számára is (Cardoso-Tavares 2018; Fenyves et al. 2017; Tyler-Lofstrom 2009). Ugyanakkor ne felejtsük el, hogy a lemorzsolódásnak létezik egy másik vetülete, ami a minőséggel van összefüggésben (Polónyi 2006).

\section{A lemorzsolódás lehetséges okai}

Az ezredforduló előtt született elméleti és empirikus munkák jelentős részének fókuszában az állt, hogy magyarázatot kerestek a lemorzsolódás, a tanulmányi sikertelenség miatti bukás, a saját felsőoktatási intézményből való kiábrándulás okaira, vagyis arra, hogy egyes „hallgatói csoportok milyen okokból nem tudják eléggé kiaknázni a kibővült felsőoktatásból adódó előnyöket" (Pusztai 2011: 63). A hallgatói lemorzsolódást vizsgáló szakirodalom számos okot fogalmaz meg annak magyarázatára, hogy a hallgatók miért hagyják el a felsőoktatást. A nemzetközi és hazai szakirodalom is négy dimenzió mentén foglalja össze a lemorzsolódás magyarázatait: 1) gazdasági okok 2) pedagógiai, pszichológiai okok 3) társadalmi, kulturális hatások 4) intézményi, szervezeti jellemzők (BergeHuang 2004; Miskolci-Bársony-Király 2018).

\section{Az empirikus vizsgálat módszerei és eszközei}

\section{A vizsgálat célkitüzései}

Empirikus vizsgálatomban a szakgimnáziumban végzett diákok lemorzsolódási kockázatának feltérképezése áll. Azt feltételezem, hogy már a felsőoktatási intézményekbe való jelentkezés előtt és a jelentkezés beadásakor lehet rizikófaktorokat azonosítani. Vizsgálatomban a következő kérdésekre keresem a választ:

1. Milyen kockázati tényezők mutathatók ki a felsőoktatásba való jelentkezés előtt és a jelentkezés benyújtásakor?

2. Mutatkoznak-e különbségek a választott szakcsoportokban, az elért felvételi pontszámokban és egyéb bevont változók esetében a gimnáziumból és a szakgimnáziumból érkezett tanulók között?

3. Milyen mértékben befolyásolják a felvételi pontszámot a szerezhető többletpontok?

\section{A vizsgálat mintája és módszere}

Munkámban két alföldi régió (Észak-Alföld régió és Dél-Alföld régió) 2017-ben érettségizett, általános felvételi eljárásra jelentkezett tanulóit vizsgálom. Elemzéseim forrása a 2017-es felvételi adatbázis. Az adatokat az SPSS program használatával elemeztem, melyben alapstatisztikákat, kereszttábla-elemzéseket, kétmintás független t-próbát és lineáris regresszióanalízist végeztem.

A vizsgálat mintáját azok az alföldi régiókból jelentkező, 2017-ben érettségizett tanulók képezik, akik az adott év szeptemberében induló képzésekre általános felvételi eljárásban jelentkeztek. Az elemzéshez megtisztítottam az adatbázist az egyértelműen beazonosítható intézménytípusokra. Így az elemzésből kimaradtak azok a tanulók, akik 
1. táblázat: 2017-ben felvételi eljárásra jelentkezők száma (fö)

\begin{tabular}{lccc}
\hline & Országos & Észak-Alföld régió & Dél-Alföld régió \\
\hline Összes jelentkező & 105868 & 16723 & 9012 \\
\hline $\begin{array}{l}\text { Ebből: 2017-ben } \\
\text { érettségizett }\end{array}$ & 38750 & 4467 & 3763 \\
\hline $\begin{array}{l}\text { Ebből: elemzésben } \\
\text { bennmaradt }\end{array}$ & - & 4443 & 3750 \\
\hline
\end{tabular}

Forrás: 2017-es felvételi adatbázis; saját szerkesztés

esetében nem lehetett biztosan megmondani, hogy az iskolájuknak melyik képzési típusában tanultak, ilyenek a felnőttképzés, a külföldön müködő iskola, a külföldi rendszerü, Magyarországon müködő iskola és az egyéb középiskola. Bár a mintavesztés nem jelentős, mégis a kutatás korlátját jelenti (1. táblázat).

A mintába került jelentkezők gimnázium és szakgimnázium szerinti megoszlásait az 1. ábra szemlélteti, melyen szembetűnő, hogy lényegesen több a gimnáziumból való továbbtanulás, ami összhangban van Szemerszki (2014) vizsgálatával.

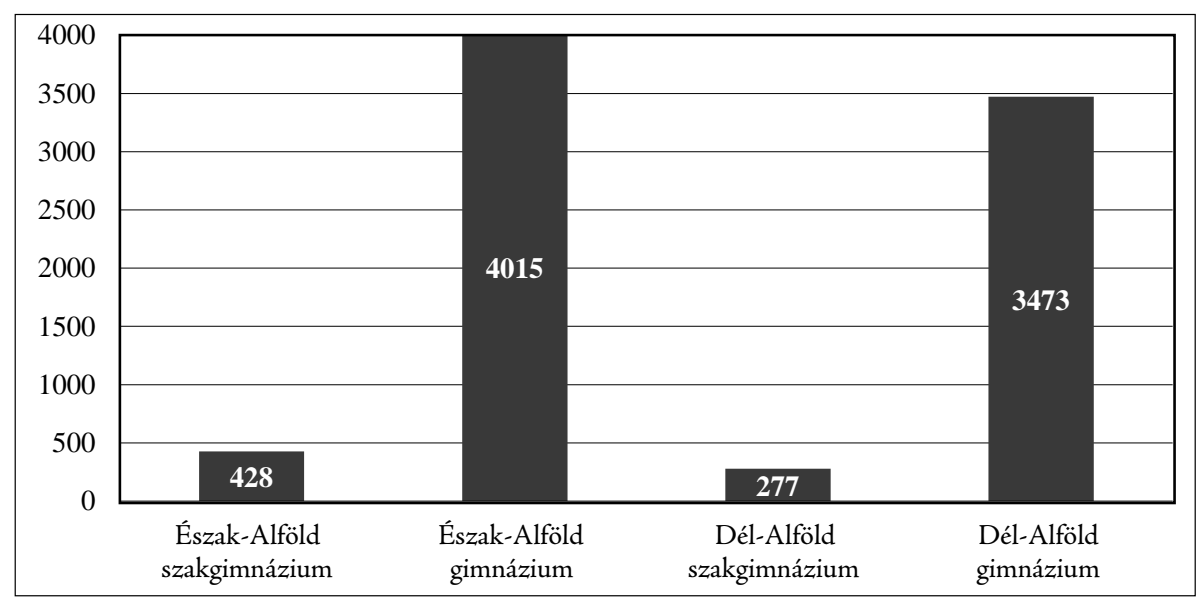

1. ábra: A vizsgálat mintájának megoszlása (fö). (Forrás: 2017-es felvételi adatbázis; saját szerkesztés)

Mindkét régióban a lányok vannak felülreprezentálva, az Észak-Alföld régióban 1819 (41\%) fiú és 2648 (59\%) lány, a Dél-Alföld régióban 1570 (42\%) fiú és 2193 (58\%) lány jelentkezett valamilyen felsőoktatási intézménybe.

\section{Eredmények és értelmezés}

Elsőként azt néztem meg, hogy a felvételi adatbázis alapján a mintába kerülők között milyen a gimnáziumból, illetve a szakgimnáziumból jelentkezett és felvett hallgatók aránya. Az Észak-Alföld régióban a gimnazisták 79\%-át vették fel, míg a szakgimnáziumból jelentkezettek 46\%-a jutott be valamelyik egyetemre, főiskolára. Hasonló tendenciát figyelhetünk meg a Dél-Alföld régióban is. A gimnáziumi diákok $80 \%$-a, míg a szak- 
2. táblázat: Nyelvvizsga-bizonyítvány megléte (\%)

\begin{tabular}{|c|c|c|c|c|c|c|}
\hline \multicolumn{2}{|c|}{ Nyelvvizsga típusa } & \multicolumn{2}{|c|}{ Gimnázium } & \multicolumn{2}{|c|}{ Szakgimnázium } & \multirow[t]{2}{*}{$\chi^{2}(p)$} \\
\hline & & nincs & van & nincs & van & \\
\hline \multirow{6}{*}{ 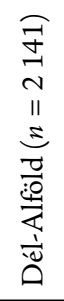 } & Középfokú $\mathrm{A}$ & 72 & 28 & 74 & 26 & $0,152(0,697)$ \\
\hline & Középfokú B & 73 & 27 & 76 & 24 & $0,208(0,648)$ \\
\hline & Középfokú C & 41 & 59 & 44 & 56 & $0,272(0,602)$ \\
\hline & Felsőfokú A & 96 & 4 & 98 & 2 & $0,528(0,467)$ \\
\hline & Felsőfokú B & 96 & 4 & 100 & 0 & $2,097(0,148)$ \\
\hline & Felsőfokú C & 79 & 21 & 82 & 18 & $0,284(0,594)$ \\
\hline \multirow{8}{*}{ 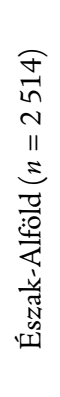 } & Érettségi C & 79 & 21 & 90 & 10 & $19,091(0,001)$ \\
\hline & Középfokú A & 46 & 54 & 49 & 51 & $0,230(0,632)$ \\
\hline & Középfokú B & 47 & 53 & 51 & 49 & $0,583(0,445)$ \\
\hline & Középfokú C & 61 & 39 & 62 & 38 & $0,040(0,841)$ \\
\hline & Felsőfokú A & 91 & 9 & 98 & 2 & $5,373(0,020)$ \\
\hline & Felsőfokú B & 91 & 9 & 98 & 2 & $5,124(0,024)$ \\
\hline & Felsőfokú C & 88 & 12 & 88 & 12 & $0,001(0,995)$ \\
\hline & Érettségi C & 82 & 18 & 94 & 6 & $37,880(0,001)$ \\
\hline
\end{tabular}

Forrás: 2017-es felvételi adatbázis; saját szerkesztés

gimnáziumból továbbtanulók 47\%-a került be valamelyik felsőoktatási intézménybe. Az eredmények azt mutatják, hogy a középiskolai intézmény típusa összefüggésben van azzal, hogy milyen arányban kerülnek be a hallgatók a felsőoktatásba $\left(\chi_{\text {ÉA }}^{2}=222,876\right.$; $p=$ 0,$\left.001 ; \chi_{\mathrm{DA}}^{2}=151,329 ; p=0,001\right)$.

Mivel a diploma megszerzéséhez már szükség van legalább egy középfokú nyelvvizsgára, ezért azt is megvizsgáltam, hogy milyen különbségek vannak a két részmintában a nyelvvizsgák megléte tekintetében. Az Észak-Alföld régióban a válaszadók csupán 56\%-a $(n=2514)$, a Dél-Alföld régióban 57\%-a $(n=2141)$ válaszolt a különböző típusú nyelvvizsga meglétének kérdésére, ami azt valószínűsíti, hogy a nem válaszolók nem rendelkeznek nyelvtudást igazoló okmánnyal. A 2. táblázat a nyelvvizsga-bizonyítvány létéről, illetve nem létéről nyilatkozókat mutatja be.

$\mathrm{A} z$ eredmények azt mutatják, hogy van összefüggés a középiskola típusa és az érettségivel megszerezhető C-típusú nyelvvizsga megléte között mindkét régióban. A DélAlföld régióban a többi nyelvvizsgatípus megléte nem függ attól, hogy a tanuló gimnáziumba vagy szakgimnáziumba járt, míg az Észak-Alföld régió esetében összefüggés tapasztalható a felsőfokú A és B típusú nyelvvizsgák megléte esetében is.

A szakirodalom alapján lemorzsolódási kockázatot jelenthet, ha a hallgatót nem abba az intézménybe veszik fel, ahová elsőként jelentkezett (Fenyves et al. 2017). Ezért kíváncsi voltam arra, hogy a felvételt nyert diákokat hányadik helyre vették fel. Az eredményeket a 2. ábra szemlélteti.

A 2. ábrán jól látható, és a statisztikai próbák $\left(\chi_{\mathrm{EA}}^{2}=11,827 ; p=0,159 ; \chi_{\mathrm{DA}}^{2}=10,264\right.$; $p=0,418)$ is megerősítik, hogy nem függ a középiskola típusától az, hogy a jelentkezőt hányadik helyen jelölt intézménybe vették fel. 


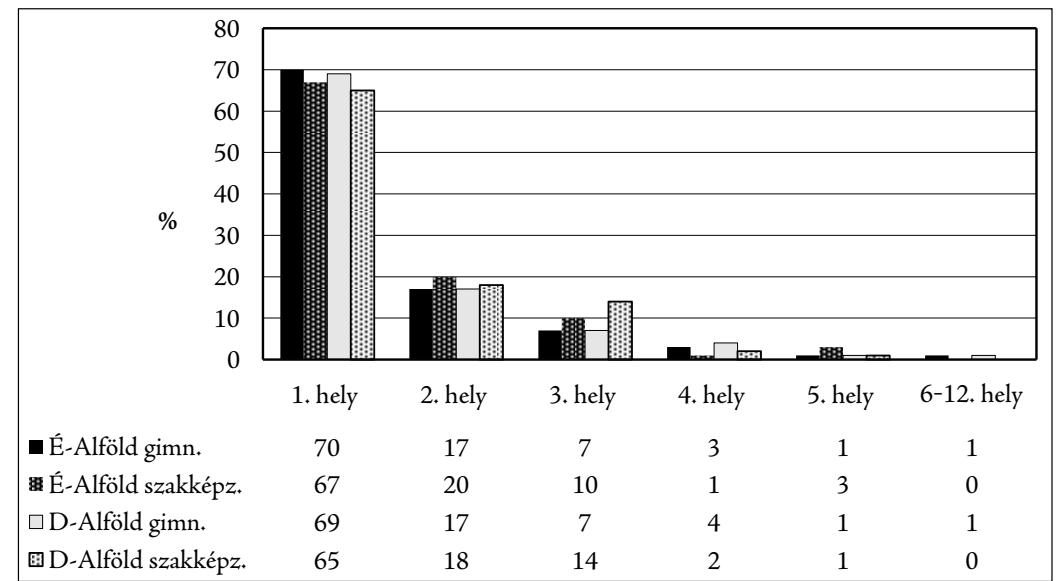

2. ábra: Hányadik helyen megjelölt intézménybe nyert felvételt a tanuló (\%).

(Forrás: 2017-es felvételi adatbázis; saját szerkesztés)

Nemcsak lemorzsolódáskutatásokból tudjuk, hogy a család szocioökonómiai státusza erős befolyással bír a tanulók tanulmányi előmenetelére (Bornstein 2015; Józsa 2004). A kedvezőtlen anyagi háttér a hallgatók jólétére és jóllétére is hatással van az egyetemeken. A költségtérítés megfizetésének terhe gondot jelenthet, főként a rosszabb anyagi-szociális körülményekből érkező hallgatók és családjuk számára (Fenyves et al. 2017; Tinto 1975). Az adatbázis nem tartalmaz a család szocioökonómiai hátterére vonatkozó információkat, így nem tudható, hogy a költségtérítéses képzésre való bejutás jelent-e az adott hallgató számára lemorzsolódási rizikófaktort. Az Észak-Alföld régióban a gimnazisták 85\%-a, a Dél-Alföld régióban 81\%-a, míg az észak-alföldi szakgimnazisták 90\%-a, a dél-

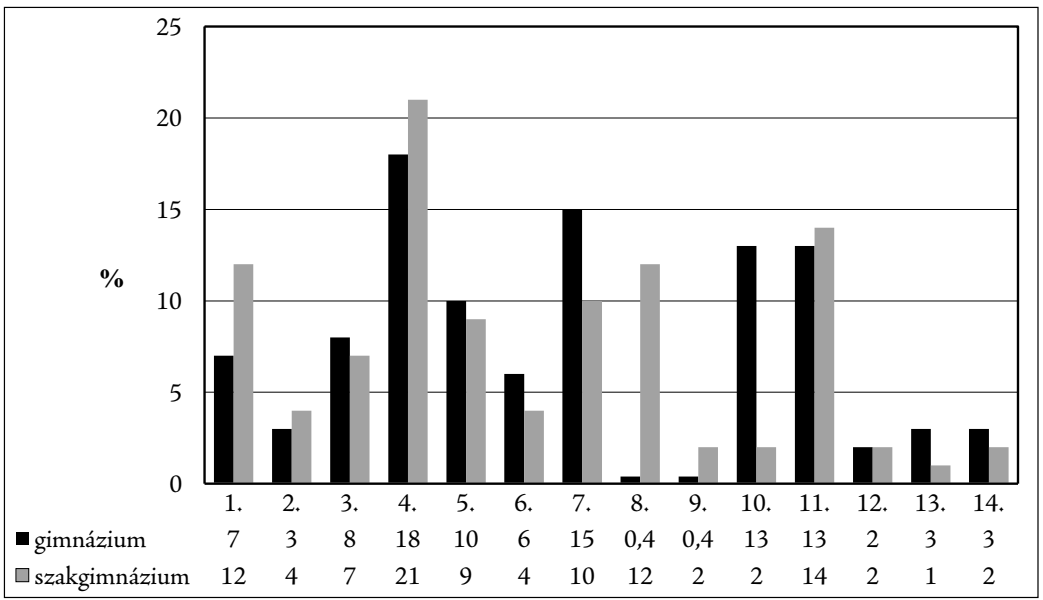

3. ábra: 2017-ben felvett hallgatók szakterületi megoszlása (Észak-Alföld régió).

(Forrás: 2017-es felvételi adatbázis; saját szerkesztés)

Megjegyzés: 1. Agrár; 2. Államtudomány; 3. Bölcsésztudomány; 4. Gazdaságtudomány; 5. Informatika; 6. Jog; 7. Műszaki; 8. Művészet; 9. Művészetközvetítés; 10. Orvos- és Egészségtudomány; 11. Pedagógia; 12 . Sport; 13. Társadalomtudomány; 14. Természettudomány 


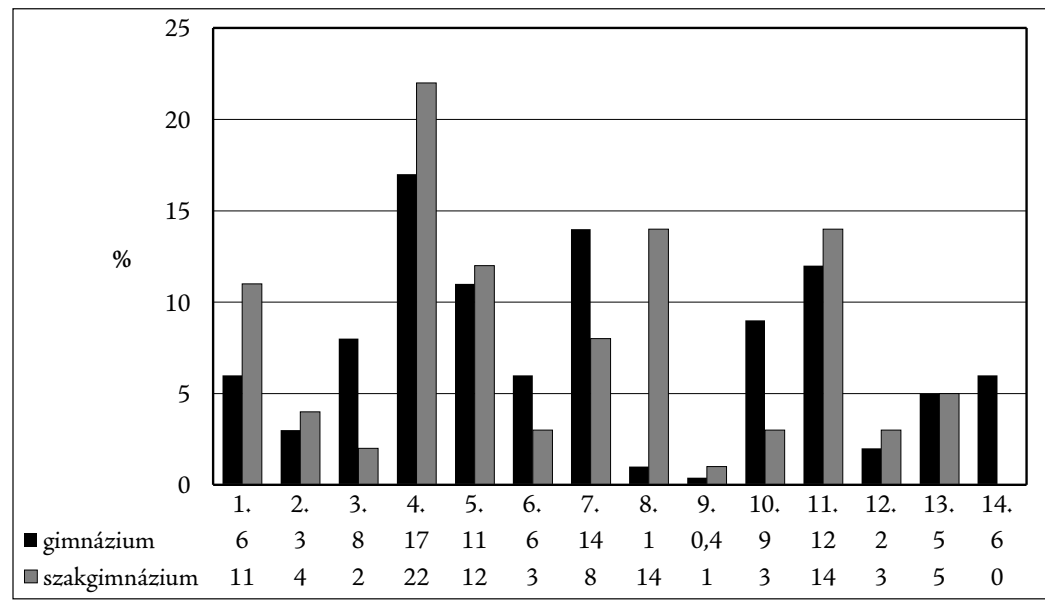

4. ábra: 2017-ben felvett hallgatók szakterületi megoszlása (Dél-Alföld régió).

(Forrás: 2017-es felvételi adatbázis; saját szerkesztés)

Megjegyzés: 1. Agrár; 2. Államtudomány; 3. Bölcsésztudomány; 4. Gazdaságtudomány; 5. Informatika; 6. Jog; 7. Müszaki; 8. Művészet; 9. Művészetközvetítés; 10. Orvos- és Egészségtudomány; 11. Pedagógia; 12. Sport; 13. Társadalomtudomány; 14. Természettudomány

alföldiek $88 \%$-a jutott be államilag finanszírozott képzésre. Az arányokban nincs különbség a középiskola típusa és a felvételt nyert finanszírozási forma között egyik vizsgált régióban $\operatorname{sem}\left(\chi_{\mathrm{EA}}^{2}=3,814 ; p=0,051 ; \chi_{\mathrm{DA}}^{2}=3,427 ; p=0,064\right)$.

Feltételezésem szerint az, hogy milyen irányban tanulnak tovább a tanulók, erősen függ attól, hogy milyen intézménytípusba jártak középiskolába. Ennek igazolására megnéztem, hogy a gimnáziumból és szakgimnáziumból jelentkező diákok milyen képzési területekre nyertek felvételt (3. és 4. ábra).

Mindkét régióban mindkét középiskolatípusból a gazdaságtudományi szakokra jelentkeztek a legnagyobb arányban a tanulók. Továbbá az informatikai, műszaki és pedagógusszakok területei is népszerűek voltak a diákok körében. Mindkét régióban az agrár és művészeti képzési terület az, ahol a szakgimnazisták, az orvos- és egészségtudomány területén a gimnazisták vannak felülreprezentálva. A természet-, társadalom- és bölcsészettudományok területén más-más képet mutat a két régió.

Kétmintás független t-próbával megvizsgáltam azt is, hogy van-e különbség a felvett gimnazisták és a szakgimnazisták között a felvételi eljárás során elért összpontszámban. Mindkét régió vizsgálata azt mutatja, hogy szignifikáns különbség van a részminták összpontszámainak átlagában (3. táblázat).

3. táblázat: A felvételi eljárásban szerzett pontszámok átlaga és szórása

\begin{tabular}{lccl}
\hline & Gimnázium & Szakgimnázium & \multirow{2}{*}{$t(p)$} \\
\cline { 2 - 3 } & átlag (szórás) & átlag (szórás) & \\
\hline Észak-Alföld & $384,47(54,569)$ & $352,62(46,707)$ & $9,156(0,001)$ \\
Dél-Alföld & $382,65(53,025)$ & $349,18(52,175)$ & $6,844(0,001)$ \\
\hline
\end{tabular}

Forrás: 2017-es felvételi adatbázis; saját szerkesztés 
$\mathrm{Az}$ összefüggések mélyebb feltárása érdekében lépésenkénti lineáris regresszióanalízissel (Stepwise módszer) megvizsgáltam a különböző típusú (emelt érettségi, nyelvvizsga, középiskolai verseny, hátrányos helyzet, GYES fogyatékosság, OKJ, sportteljesítmény) többletpontok magyarázó erejét a felvételi eljárás során elért összpontszámra. ${ }^{2} \mathrm{~A} z$ eredmények alapján az Észak-Alföld régióban az emelt szintű érettségi vizsgáért kapott pluszpontok 29\%-ban magyarázzák meg az összpontszámot, a Dél-Alföld régióban 24\%-ban. ${ }^{3} \mathrm{Az}$ OKJ-n és GYES-en kívül az elemzésbe bevont többi független változó is szignifikáns magyarázóerővel bír a tanulók által elért összpontszám különbségeiben. A nyelvvizsga az Észak-Alföld és a Dél-Alföld régióban is $19 \%$-ban magyarázza az összpontszámot, míg a középiskolai versenyeredmények az Észak-Alföld régióban 3\%-os, a Dél-Alföldön 4\%-os magyarázóerővel bírnak. A hátrányos helyzetért kapott többletpontok 2\%-os szignifikáns magyarázóerővel bírnak az Észak-Alföld régióban, míg a sportteljesítményért és a fogyatékkal élésért kapott többletpontok együtt csupán 1\%-át magyarázzák az összpontszámnak. A Dél-Alföld régióban a sportteljesítményért, a hátrányos helyzetért, fogyatékosságért kapott pluszpontok együttes szignifikáns magyarázóereje 2\%. Az Észak-Alföld régióban a bevont független változók $54 \%$-ban $\left(R^{2}=0,54\right)$, a Dél-Alföld régióban 49\%-ban $\left(R^{2}=0,54\right)$ magyarázzák az összpontszámot.

Szintén lépésenkénti lineáris regresszióval vizsgáltam meg középiskolatípusonként a bevont változók magyarázóerejét. Az Észak-Alföldön mindkét iskolatípusban a legerősebb magyarázóerővel az emelt érettségi rendelkezik $\left(F_{\text {ÉAszakg }}=11,245 ; p=0,001\right.$; $\left.F_{\text {ÉAgimn }}=1103,362 ; p=0,001\right)$. A szakgimnáziumban végzetteknél a középiskolai versenyt a nyelvvizsga követi, majd a hátrányos helyzet. A gimnazistáknál a nyelvvizsga lép be a második legerősebb magyarázóerőként, ezt követi a középiskolai verseny, a hátrányos helyzet és legvégül a sportteljesítményért kapott pluszpontok. A gimnazistáknál hasonló képet mutat a Dél-Alföld régió azzal a kiegészítéssel, hogy itt volt olyan tanuló, aki az OKJ-ért $(F=331,569 ; p=0,001)$ kapott többletpontot. A Dél-Alföld régió szakgimnáziumában végzett tanulók négy területen szereztek többletpontot, melyek közül a legerősebb magyarázóerővel a középiskolai verseny $(F=13,815 ; p=0,001)$ bír 17\%-kal. Másodikként a nyelvvizsgáért kapott pluszpont áll, majd ezt követik az emelt szintü érettségiért és a fogyatékosággal élésért kapott többletpontok.

\section{Összegzés}

Az utóbbi évtizedekben egyre nagyobb hangsúlyt kap a lemorzsolódás jelenségének feltárása az oktatás minden szintjén. A felsőoktatásban a lemorzsolódás elsősorban a demokratizálódás következtében jelentkező expanzió és tömegesedés nyomában járó jelenség. Munkámban nem ezzel, hanem a hallgatóra, intézményre és a társadalomra nézve problémát jelentő lemorzsolódás feltérképezésére helyeztem a hangsúlyt.

Kutatásomban a 2017-es felvételi adatbázis alapján a Dél- és Észak-Alföld régiókban található gimnáziumok és szakgimnáziumok 2017-ben érettségizett felvételizőit vizsgál-

A modell(ek) illeszkedése minden esetben megfelelő $(p<0,001)$.

$\mathrm{A} z$ egyes változók magyarázóerejét a függő változó és az adott független változó közötti korrelációs együttható $(r)$ és a sztenderdizált regressziós együttható $(\beta)$ szorzataként számítottam ki. 
tam. Mivel az adatbázis csak korlátozott adatokat tartalmaz, ezért az affektív és szociális, illetve szocioökonómiai faktorok vizsgálatára jelen elemzésben nem térhettem ki.

Vizsgálatomban elsőként arra kerestem a választ, hogy a felvételi jelentkezés időpontjában milyen rizikófaktorok azonosíthatók, melyek a későbbi lemorzsolódásban szerepet játszhatnak. Magyar sajátosságként a középfokú komplex nyelvvizsga megléte a diplomaszerzés egyik kritériuma. Az elemzésből jól látszik, hogy a válaszadók kevesebb mint fele rendelkezik a felvételi időpontjában nyelvvizsgával. A középfokú nyelvvizsgák esetében hasonló mintázatot mutat a két vizsgált régió iskolatípusonként, míg a felsőfokú nyelvvizsga-bizonyítvány meglétében eltérő képet láthatunk. Szignifikáns különbség csupán az érettségin megszerezhető $C$ típusú nyelvvizsga meglétében van mindkét régióban az iskolatípusban.

A szakirodalom alapján lemorzsolódási rizikófaktort jelenthet, ha a hallgatót nem arra a képzésre veszik fel, amire elsőként jelentkezett, ezért megvizsgáltam, hogy a felvett tanulók milyen arányban kerültek be az első helyen megjelölt szakra. Mindkét régióban mindkét típusú középiskolából jelentkező diákok több mint hattizedét felvették az első helyre. A vizsgált hallgatók kevesebb mint négytizedénél jelentkezhetnek az intézményi jellemzők és a saját elképzelések közötti nem megfelelő illeszkedések, más elvárások, melyek a felsőoktatási intézmény elhagyásához vezethetnek.

Második kérdésem a középiskolatípusok közötti különbségekre vonatkozott. Az adatbázis elemzése során azt találtam, hogy szignifikáns különbséget jelent, hogy a tanulók gimnáziumból vagy szakgimnáziumból jelentkeznek továbbtanulni. Az intézménytípusok közötti különbség a szakok iránti érdeklödésben is megmutatkozik: szakgimnáziumokból többen nyertek felvételt az agrár és művészeti szakokra, mint a gimnáziumokból, míg az orvos- és egészségtudományi képzések esetében épp fordított a tendencia. Szignifikáns különbség mutatkozik a felvételt nyert tanulók összpontszámában is, a szakgimnáziumokból továbbtanulók összpontszámának átlaga alacsonyabb, mint a gimnáziumokból továbbtanulóké.

Harmadsorban arra voltam kíváncsi, hogy a felvételi eljárásban szerezhető többletpontok milyen mértékben magyarázzák az összpontszámot. A kapott adatokból az látszik, hogy az emelt érettségi, a nyelvvizsga és a középiskolai versenyekért kapott többletpontok mindkét régió mindkét iskolatípusában szignifikáns magyarázóerővel bírnak.

A vizsgálat eredményei alapján elmondható, hogy már a jelentkezés pillanatában azonosíthatók olyan rizikófaktorok, melyek később a felsőoktatási tanulmányok idő előtti, diplomaszerzés nélküli elhagyásához vezethetnek. A középiskola típusának befolyása a felvételi sikerességére és az azonosított kockázati tényezőkre nem mutat egységes mintázatot. A kutatás korlátai között említendő, hogy a lehetséges kockázati tényezőket csak két régióra fókuszálva elemeztem, továbbá kihagytam a mintából azon intézmények tanulóit, akiknél nem volt egyértelmű az iskolatípus beazonosítása. Mindez limitálja az eredmények általánosíthatóságát, azonban a két régióban kapott közel azonos eredmények erősítik egymást. A rizikótényezők mélyebb feltárása érdekében szükséges az adatbázisok elemzését interjúval vagy kérdőíves vizsgálattal kiegészíteni. Kutatási terveim között szerepel egy olyan longitudinális vizsgálat, ami a szakgimnáziumok végzős diákjait követi nyomon a felsőoktatás éveiben, mely reményeim szerint tovább bővítheti tudásunkat a lemorzsolódás okairól és a középiskola típusának hatásáról. 


\section{IRODALOM}

Berde É. (2013) A felsőoktatás lehetséges létszámpályái Magyarországon. Statisztikai Szemle, Vol. 91. No. 1. pp. 57-76.

Berge, Z. L. \& Huang, Y. P. (2004) A Model for Sustainable Student Retention: A Holistic Perspective on the Student Dropout Problem with Special Attention to e-Learning. DEOSNEWS, Vol. 13. No. 5. http://citeseerx.ist.psu.edu/viewdoc/download; jsessionid=DF50520CC6164BF520C742FC8B39ACFC?doi=10.1.1.129.1495\&rep=rep1 \&type $=$ pdf [Letöltve: 2019. 03.31.]

Bornstein, M. H. (2015) Children's Parents. In: R. Lerner, M. Bornstein, \& T. Leventhal (eds) Handbook of Child Psychology and Developmental Science. (Volume 4, Ecological Settings and Processes, Chapter 3.) Hoboken(NJ) Wiley. pp. 1-78.

Cardoso S. \& Tavares, O. (2018) Students' Drop Out, Higher Education. In: P. Teixeira \& J. Shin (eds) Encyclopedia of International Higher Education Systems and Institutions. Dordrecht, Springer. pp. 1-3.

Engler Á. (2017) A család mint erőforrás. Budapest, Gondolat Kiadó.

Fehérvári A. (ed.) (2008) Szakképzés és lemorzsolódás. Kutatás közben 283. Budapest, Oktatáskutató és Fejlesztő Intézet.

Fenyves V., Bácsné Bába É., Szabóné Szőke R., Kocsis I., Juhász Cs., Máté E. \& Pusztai G. (2017) Kísérlet a lemorzsolódás mértékének és okainak megragadására a Debreceni Egyetem Gazdaságtudományi Kar példáján. Neveléstudomány, Vol. 5. No. 3. pp. 5-14. http://nevelestudomany.elte.hu/downloads/2017/ nevelestudomany_2017_3_5-14.pdf [Letöltve: 2019.03. 28.]

Horn, L. J. (1998) Stopouts or Stayouts? Undergraduates Who Leave College in Their First Year. Washington DC, U.S. Department of Education. National Center for Education Statistics. NCES 1999-087. https://nces.ed.gov/pubs99/1999087.pdf [Letöltve: 2019. 03. 28.]

Hrubos I. (1999) A felsőoktatás dilemmái a tömegessé válás korszakában. Budapest, Oktatáskutató Intézet.

Józsa K. (2004) Az első osztályos tanulók elemi alapkészségeinek fejlettsége. Egy longitudinális kutatás első mérési pontja. Iskolakultúra, Vol. 14. No.11. pp. 3-16.

Kozma T. (2004) Kié az egyetem? A felsőoktatás nevelésszociológiája. Budapest, Új Mandátum Kiadó.

Lukács F. \& Sевő T. (2005) Az egyetemi lemorzsolódás kérdőíves vizsgálata. Iskolakultúra, Vol. 25. No. 10. pp. 78-86.

Macqueen, S. (2017) Narratives from Non-traditional Students in Higher Education. The Thesis Is Submitted for the Degree of Doctor of Philosophy at the University of Queensland in 2017. University of Queensland.

Miskolci P., Bársony F. \& Király G. (2018) Hallgatói lemorzsolódás a felsőoktatásban: elméleti, magyarázati utak és kutatási eredmények összefoglalása. Iskolakultúra, Vol. 28. No. 3-4. pp. 87-105.

MolnÁr B. (2012) A felsőoktatásban tapasztalható lemorzsolódás csökkentése innovatív módszerekkel. In: BudA A. \& KIss E. (eds) Interdiszciplináris pedagógia és a felsőoktatás alakváltozásai. A VII. Kiss Árpád emlékkonferencia elöadásainak szerkesztett változata. Debrecen, Kiss Árpád Archivum Könyvsorozata Debreceni Egyetem Neveléstudományok Intézete. pp. 350-357. http://www.kissarpadkonf.unideb.hu/2011/downloads/ kissarpad2011_kotet.pdf [Letöltve: 2019. 03. 28.] 
PolóNyi I. (2006) A munkaerőpiacra orientált felsőoktatási minőségbiztosítás. In: BÁLINT J., Polónyi I. \& Siknós B. (eds) A felsőoktatás minősége. Budapest, Felsőoktatási Kutatóintézet. pp. 10-38.

Polónyi I. (2017) Az oktatáspolitika műveltségképe. Neveléstudomány, Vol. 5. No. 1. pp. 5-14. http://nevelestudomany.elte.hu/downloads/2017/nevelestudomany_2017_1_5-14. pdf [Letöltve: 2019. 03. 28.]

Pusztai G. (2011) A láthatatlan kéztôl a baráti kézig. Hallgatói értelmezöi közösségek. Budapest, Új Mandátum Kiadó.

SÁska G. (2014) Húsz év köz- és felsőoktatásáról, körkép. Iskolakultúra, Vol. 24.

No. 2. pp. 3-18. http://epa.oszk.hu/00000/00011/00182/pdf/EPA00011_ iskolakultura_2014_2_003-018.pdf [Letöltve: 2019.03.28.]

Szemerszki M. (2014) A középiskolából a felsőoktatásba. Jelentkezési és felvételi tendenciák. Felsőoktatási Mübely, No. 1. pp. 47-63.

Tinto, V. (1975) Dropouts from Higher Education: A Theoretical Synthesis of Recent Literature. Review of Educational Research, Vol. 45. No. 1. pp. 89-125.

Tyler, J. H. \& Lofstrom, M. (2009) Finishing High School: Alternative Pathways and Ddroout Recovery. Future of Children, Vol. 19. No. 1. pp. 77-103.

Veroszta Zs. (2010) A felsőoktatás társadalmi felelőssége a hallgatói értékkészletekben. Educatio, Vol. 19. No. 2. pp. 230-240.

A cikk a Creative Commons Attribution 4.0 International License (https://creativecommons.org/licenses/ by/4.0/) feltételei szerint publikált Open Access közlemény, melynek szellemében a cikk bármilyen médiumban szabadon felhasználható, megosztható és újraközölhető, feltéve, hogy az eredeti szerző és a közlés helye, illetve a CC License linkje és az esetlegesen végrehajtott módosítások feltüntetésre kerülnek. (SID_1) 